\title{
SOSIALISASI PEMERIKSAAN METODE IVA PADA WANITA USIA SUBUR (WUS) UNTUK DETEKSI DINI KANKER SERVIKS
}

\author{
Neneng Julianti ${ }^{1)}$ \\ 1)Program Studi DIII Kebidanan, Universitas Medika Suherman, Bekasi, Jawa Barat, Indonesia \\ Corresponding author: Neneng Julianti \\ E-mail: julianti.neneng@gmail.com
}

\section{Diterima 18 Oktober 2021, Direvisi 25 Oktober 2021, Disetujui 26 Oktober 2021}

\begin{abstract}
ABSTRAK
Angka kejadian kanker serviks yang masih cukup tinggi dipengaruhi olehperilaku deteksi dini yang masih rendah. Menurut Riskesdas 2018 tumor/kanker di Indonesia menunjukkan adanya peningkatan dari 1,4 per 1000 pendudukdi tahun 2013 menjadi 1,79 per 1000 penduduk pada tahun 2018. Hasil studi pendahuluan yang dilakukan di dusun I Desa Bantarjaya pada tahun 2021 dari 30 wanita usia subur, terdapat 23 orang tidak tahu apa itu IVA dan belum melakukan pemeriksaan IVA dan 7 orang sudah melakukan IVA Test. Sehingga capaian masih rendah karena minat dan motivasi wanita usia subur untuk melakukan pemeriksaan IVA untuk mendeteksi secaradini kanker serviks masihkurang. Pendidikan kesehatan perlu dilakukan untuk meningkatkan pengetahuan dan minat ibu (WUS) tentang kanker serviks. Kegiatan pengabdian pada masyarakat ini memiliki tujuan untuk meningkatkan perilaku ibu diwilayah kerja Puskesmas Pebayuran dalam melakukan deteksi dini kanker serviks melalui pemeriksaan metode IVA. Metode pelaksanaan adalah dengan memberikan sosialisasi / penyuluhan tentang materi pemeriksaan metode IVA untuk mendeteksi secara dini kanker serviksdan dilanjutkan dengan tanya jawab dengan peserta. Hasil yang didapatkan dari kegiatan pengabdian masyarakat ini adalah mengalami peningkatan pengetahuan dan minat wanita usia subur (WUS) dalam melakukan deteksi dini kanker serviks. Dari 45 responden sebelum sosialisasi memiliki pengetahuan dalam kategori cukup $64,41 \%$, mengalami peningkatan pengetahuan dalam kategori baik $93,53 \%$. Dari hasil sosialisasi / penyuluhan dan evaluasi beberapa wanita usia subur bersediauntukmelakukanpemeriksaanIVA di Puskesmas Pebayuran, hal ini menunjukkan bahwa adanya peningkatan motivasi setelah pelaksanaan kegiatan sosialisasi/penyuluhan.Sosialisasi / penyuluhan pemeriksaan metode IVA pada wanita usia subur dapat meningkatkan kesadaran wanita usia subur dalam melakukan pemeriksaan IVA untuk mendeteksi secara dini dalam upaya mengendalikan kejadian kanke rserviks. Setelah pelaksanaan pengabdian masyarakat ini diharapkan ibu akan tetap rutin melakukan deteksi dini dengan didukung peran aktifkader dan tenaga kesehatan.
\end{abstract}

KataKunci : sosialisasi; pemeriksaan IVA; wanita usia subur.

\begin{abstract}
Recently, the high incident number of servics cancer was influenced by the low early detected behavior. According to Riskesdas 2018, it stated that tumor/cancer in Indonesia increased 1,4 per 1000 citizen in 2013 to 1,79 per 1000 citizen in 2018 . The preliminary study result was conducted at Dusun 1, Bantarjaya Village in 2021 of 30 childbearing age women. There were 23 women who did not know what IVA test was, and there were 7 women who had done the IVA test. Therefore, the expected target of servics cancer test was still in low level. It all was because they did not have interest and motivation to do the IVA test for preventing action of servics cancer.The health education was required to increase the knowledge and interest of a mother (WUS) to servics cancer. This society study was dedicated to enhance the mother's behavior at working area of Pabayuran Public Health Centre. It was in order to detect the early test of servics cancer through IVA method test.The result stated that the society dedication activity succeeded to increase the interest and motivation of the childbearing age women (WUS) to take the early detected test of servics cancer. Before doing the socialization, there were 45 respondents had the average category knowledge of servics cancer, and the score was $64,41 \%$. Moreover, after doing the socialization, it became $93,53 \%$. Based on the socialization / counseling, there were several childbearing age women who conducted the IVA test at Pabayuran Public Health Centre. It showed that there wassome enhancement of motivation after doing the socialization/ counseling.The socialization/counseling of IVA method test on childbearing age women increased the childbearing age women awareness to conduct the IVA test for controlling the servics cancer incident. The society dedication activity purposed to every mother to take the IVA
\end{abstract}


test regularly for early detected test of service cancer which was supported by the active cadres and health workers.

Key words : socialization; IVA test; childbearing age women

\section{PENDAHULUAN}

Salah satu penyakit yang dapat mengganggu kesehatan organ reproduksi wanita adalah kanker serviks yang merupakan kanker yang paling sering menyerang wanita di seluruh dunia. (Kemenkes, 2013). Bahkan semakin meningkat dari tahun ke tahun, hal itu dapat dikarenakan bergesernya gaya hidup manusia, termasuk di dalamnya pola makan, pola hubungan seksual, serta maraknya bahan tambahan makanan, minuman maupun kosmetika yang ikut memicu kanker.

Kanker serviks merupakan suatu penyakit keganasan pada leher rahim atau serviks uteri. Sekitar 90\% atau 270.000 kematian akibat kanker serviks pada tahun 2015 terjadi di negara berpenghasilan rendah dan menengah. Tingkat kematian yang tinggi dari kanker serviks secara global dapat dikurangi melalui pendekatan komprehensif yang mencakup pencegahan, diagnosis dini, screening yang efektif dan program pengobatan. (WHO, 2016). Daerah dengan angka kematian kurang dari 2 per 100.000 di Asia Barat, Eropa Barat dan Australia/Selandia Baru sedangkan negara dengan angka kematian lebih dari 20 per 100.000 yaitu Melanesia $(20,6)$, Afrika Tengah $(22,2)$ dan Afrika Timur $(27,6)$. Berdasarkan data WHO,2016 di Indonesia kanker serviks menempati urutan kedua setelah kanker payudara. Didapatkan kasus baru kanker serviks sekitar 20.928 dan kematian akibat kanker serviksdengan persentase 10,3\%. (WHO, 2016).

Berdasarkan data Riskesdas 2018, prevalensi tumor/kanker di Indonesia menunjukkan adanya peningkatan dari 1,4 per 1000 pendudukdi tahun 2013 menjadi 1,79 per 1000 penduduk pada tahun 2018. Prevalensi kanker tertinggi adalahYogyakartayaitu4,86 per 1000 penduduk, diikuti Sumatera Barat 2,47 per 1000 penduduk dan Gorontalo2,44 per 1000 penduduk. (Riskesdas, 2018).

Salah satu pemeriksaan alternatif untuk mendeteksi kanker serviks dengan biaya yang relatif lebih murah adalah inspeksi visual dengan asam asetat (IVA). Inspeksi visual dengan asam asetat adalah pemeriksaan serviks secara langsung tanpa menggunakan alat pembesaran (mata telanjang) setelah pengusapan serviks dengan asam asetat 3-5\%. Pemeriksaan ini bertujuan untuk mendeteksi secara dini adanya lesi prakanker atau kanker melalui warna epitel serviks menjadi putih yang disebut acetowhite. Metode skrining IVA ini relative lebih mudah dan dapat dilakukan oleh dokter umum, bidan atau perawat yang telah terlatih melakukan metode ini. Tingginya angka kematian akibat kanker serviks di dunia menandakan bahwa kita patut waspada dan mengenali tanda-tandanya. (Dewi L, Supriati E, 2014).

Hasil studi pendahuluan yang dilakukan di dusun I desa bantarjaya pada bulan Maret tahun 2021terdapat jumlah pasangan usia subur dari bulan februari sampai april sebanyak 300 wanita usia subur (WUS) . Dari hasil studi pendahuluandi dusun I desa bantarjaya pada bulan maret dengan 30 wanita usia subur. 23 orang tidak tahu apa itu IVA dan belum melakukab pemeriksaanIVA atau kurangnya informasi, 7 orang sudah melakukan IVA Test, Terdapat PUS yang berminat melakukan pemeriksaan IVA sebanyak 10 orang atau $33,3 \%$ alasan nya untuk kesehatan dan ingin mengetahui skrining kanker serviks, dan wanita usia subur yang tidak berminat melakukan pemeriksaan iva sebanyak 20 orang atau $66,6 \%$ alasannya karena takut, malu dan takut tidak boleh sama suami atau keluarga.Kanker leher rahim merupakan masalah kesehatan perempuan di Indonesia dengan angka kejadian dan angka kematian yang tinggi. Banyak faktor yang berhubungan dengan minat Wanita Usia Subur (WUS) terhadap pemeriksaan IVA sehingga kegiatan pengabdian kepada masyarakat itu dilakukan dengan judul kegiatan "Sosialisasi pemeriksaan Metode IVA pada Wanita Usia Subur (WUS) untuk Deteksi Dini Kanker Serviks di Desa Bantarjaya Pebayuran pada Tahun 2021" .

Banyak faktor yang berhubungan dengan minat Wanita Usia Subur (WUS) terhadap pemeriksaan IVA sehingga untuk meningkatkan minat Wanita Usia Subur (WUS) di Desa Bantarjaya terhadap pemeriksaan IVA. Berdasarkan dari data tersebut, masalah yang dapat dirumuskan dalam kegiatan ini adalah “ Bagaimana cara meningkatkan minat Wanita Usia Subur (WUS) dalam melakukan pemeriksaan IVA di desa bantarjaya Pebayuran 2021? “.

Kegiatan ini bertujuan untuk memberikan pengetahuan tentang pemeriksaan IVA dalam mendeteksi secara dini kanker leher rahim pada Wanita Usia Subur (WUS) di Desa Bantarjaya tahun 2021. 
Mamfaat dalam kegiatan ini adalah memberikan pengetahuan tentang pemeriksaan metode IVA untuk meningkatkan minat wanita usia subur dalam melakukan pemeriksaan metode IVA di Desa Bantarjaya.

\section{METODE}

Metode yang digunakan untuk melakukan pengabdian kepada masyarakat ini adalah melalui beberapa tahap yaitu tahap persiapan, pelaksanaan dan evaluasi kegiatan. Pada bagian tahap persiapan mulai dari melakukan penjajakan Puskesmas Pebayuran dengan melihat besaran masalah yang ada dan rencana yang dilakukan yaitu dengan mengumpulkan kader Desa bantarjaya yang aktif. Fungsi dari kader tersebut agar dapat memberikan support kepada WUS sehingga minat WUS untuk melakukan kunjungan kePuskesmas dan melakukan pemeriksaan metode IVA dapat meningkat. Kemudian kami melakukan pendekatan kepada Kepala Puskesmas, Bidan Koordinator, Bidan Desa, Kader dan Kepala Desa Bantarjaya. Kader sebelumnya sudah diberikan pembekalan oleh kami dan pihak puskesmas untuk menyampaikan pentingnya pemeriksaan metode IVA deteksi dini kanker serviks.

Selanjutnya melakukan pelaksanaan kegiatan dengan membentuk Tim pengabdian kepada masyarakat yang terdiri dari dosen serta kader agak kerjasama yang dilakukan dapat secara maksimal demi tercapainya tujuan akhir pengabdian yang maksimal. Dimana kegiatan ini dilakukan pada Hari Jumat, 21 Mei 2021 Pukul 09.00 s/d 16.00 WIB di Balai Desa Bnatarjaya dengan jumlah 45 peserta (WUS) yang di bagi menjadi 3 sesi dikarenakan keadaan pandemic covid 19. Mulai dari memberikan pembekalan kepada kader dan menyebarkan soal Pre tes untuk melihat secara garis besar pengetahuan WUS terhadap pemeriksaan IVA. Kemudian memberikan penyuluhan dan informasi terkait kanker servik serta deteksi dini menggunakan IVA. Pelaksanaan penyuluhan dan pemberian informasi ini menggunakan leaflet sehingga WUS memahami pentingnya deteksi dini IVA untuk mencegah kanker servik. Kemudian setalah penyuluhan pelaksana memberikan pertanyaan Post Tes untuk melihat apakah adanya peningkatan pengetahuan dan minat WUS dalam melakukan pemeriksaan metode IVA. Kemudian selanjutnya melakukan evaluasi kegiatan pada Hari Senin, 31 Mei 2021 Pukul 09.00 s/d 15.00 WIB di Balai Desa Bantarjaya untuk menilai efektifitas dari pelaksanaan pengabdian kepada masyarakat ini dengan malakukan wawancara untuk mengetahui peningkatan jumlah WUS yang akan melakukan peneriksaan metode IVA di Puskesmas Pebayuran.

\section{HASIL DAN PEMBAHASAN Hasil}

Kegiatan pengabdian kepada masyarakat ini berupa sosialisasi metode pemeriksaan IVA pada wanita usia subur di Desa Bantarjaya Kecamatan Pebayuran berupa penyuluhan dengan memberikan materi tentang pemeriksaan IVA dan diskusi dengan wanita usia subur. Kegiatan ini telah terlaksana dengan lancar sesuai dengan rencana. Soal pre test dilakukan sebelum pemberian materi penyuluhan untuk melihat pengetahuan dan sikap responden. Proses penyampaian materi berlangsung secara baik dan lancar. Pada sesi Tanya jawab beberapa ibu tertarik untuk bertanya tentang materi yang telah disampaikan. Hal tersebut menunjukan antusiasme dari para responden kegiatan untuk meningkatkan pemahamannya tentang kanker serviks dan dapat meningkatkan minat wanita usia subur untuk melakukan pemeriksaan IVA. Sesi berikutnya adalah sesi Tanya jawab dan post test yaitu untuk menilai pengetahuan dan pemahaman ibu setelah di berikan penyuluhan.

Menurut tabel 5.1 Menunjukan bahwa sebelum dilakukan sosialisasi / penyuluhan dari 45 responden memiliki pengetahuan tentang pemeriksaan IVA dalam kategori cukup (64,41\%), sesudah dilakukan penyuluhan/sosialisasi dari 45 responden terdapat peningkatan pengetahuan / pemahaman sebanyak 93,53\% dalam kategori baik tentang pemeriksaan IVA. Sehingga persentase mengalami peningkatan pengetahuan/pemahaman sebesar $29,12 \%$. 
Tabel 1. Rekapitulasi pre test dan post test

\begin{tabular}{|c|c|c|c|c|c|c|}
\hline No & Responden & $\begin{array}{l}\text { Skor } \\
\text { Pre } \\
\text { Tes }\end{array}$ & Persentase & $\begin{array}{l}\text { Skor } \\
\text { Post } \\
\text { Tes }\end{array}$ & Persentase & $\begin{array}{c}\text { Peningkatan } \\
(\%)\end{array}$ \\
\hline 1 & R1 & 8 & $72,7 \%$ & 10 & $90,9 \%$ & $18,2 \%$ \\
\hline 2 & R2 & 8 & $72,7 \%$ & 11 & $100 \%$ & $27,3 \%$ \\
\hline 3 & R3 & 8 & $72,7 \%$ & 10 & $90,9 \%$ & $18,2 \%$ \\
\hline 4 & R4 & 7 & $63,6 \%$ & 10 & $90,9 \%$ & $27,3 \%$ \\
\hline 5 & R5 & 7 & $63,6 \%$ & 9 & $81,8 \%$ & $18,2 \%$ \\
\hline 6 & $\mathrm{R} 6$ & 8 & $72,7 \%$ & 11 & $100 \%$ & $27,3 \%$ \\
\hline 7 & R7 & 9 & $81,8 \%$ & 11 & $100 \%$ & $18,2 \%$ \\
\hline 8 & R8 & 7 & $63,6 \%$ & 10 & $90,9 \%$ & $27,3 \%$ \\
\hline 9 & R9 & 8 & $72,7 \%$ & 10 & $90,9 \%$ & $18,2 \%$ \\
\hline 10 & R10 & 8 & $72,7 \%$ & 10 & $90,9 \%$ & $18,2 \%$ \\
\hline 11 & R11 & 6 & $54,5 \%$ & 10 & $90,9 \%$ & $36,4 \%$ \\
\hline 12 & R12 & 7 & $63,6 \%$ & 10 & $90,9 \%$ & $27,3 \%$ \\
\hline 13 & R13 & 8 & $72,7 \%$ & 11 & $100 \%$ & $27,3 \%$ \\
\hline 14 & R14 & 8 & $72,7 \%$ & 11 & $100 \%$ & $27,3 \%$ \\
\hline 15 & R15 & 6 & $54,5 \%$ & 10 & $90,9 \%$ & $36,4 \%$ \\
\hline 16 & R16 & 6 & $54,5 \%$ & 11 & $100 \%$ & $45,5 \%$ \\
\hline 17 & R17 & 8 & $72,7 \%$ & 11 & $100 \%$ & $27,3 \%$ \\
\hline 18 & R18 & 7 & $63,6 \%$ & 11 & $100 \%$ & $36,4 \%$ \\
\hline 19 & R19 & 7 & $63,6 \%$ & 10 & $90,9 \%$ & $27,3 \%$ \\
\hline 20 & R20 & 5 & $45,4 \%$ & 10 & $90,9 \%$ & $45,5 \%$ \\
\hline 21 & R21 & 8 & $72,7 \%$ & 11 & $100 \%$ & $27,3 \%$ \\
\hline 22 & R22 & 8 & $72,7 \%$ & 11 & $100 \%$ & $27,3 \%$ \\
\hline 23 & R23 & 5 & $45,4 \%$ & 9 & $81,8 \%$ & $36,3 \%$ \\
\hline 24 & R24 & 5 & $45,4 \%$ & 10 & $90,9 \%$ & $45,5 \%$ \\
\hline 25 & R25 & 8 & $72,7 \%$ & 11 & $100 \%$ & $27,3 \%$ \\
\hline 26 & R26 & 8 & $72,7 \%$ & 11 & $100 \%$ & $27,3 \%$ \\
\hline 27 & R27 & 8 & $72,7 \%$ & 10 & $90,9 \%$ & $18,2 \%$ \\
\hline 28 & R28 & 8 & $72,7 \%$ & 11 & $100 \%$ & $27,3 \%$ \\
\hline 29 & R29 & 7 & $63,6 \%$ & 10 & $90,9 \%$ & $27,3 \%$ \\
\hline 30 & R30 & 7 & $63,6 \%$ & 10 & $90,9 \%$ & $27,3 \%$ \\
\hline 31 & R31 & 6 & $54,5 \%$ & 9 & $81,8 \%$ & $27,3 \%$ \\
\hline 32 & R32 & 7 & $63,6 \%$ & 10 & $90,9 \%$ & $27,3 \%$ \\
\hline 33 & R33 & 7 & $63,6 \%$ & 9 & $81,8 \%$ & $18,2 \%$ \\
\hline 34 & R34 & 8 & $72,7 \%$ & 11 & $100 \%$ & $27,3 \%$ \\
\hline 35 & R35 & 8 & $72,7 \%$ & 10 & $90,9 \%$ & $18,2 \%$ \\
\hline 36 & R36 & 7 & $63,6 \%$ & 10 & $90,9 \%$ & $27,3 \%$ \\
\hline 37 & R37 & 6 & $54,5 \%$ & 10 & $90,9 \%$ & $36,4 \%$ \\
\hline 38 & R38 & 6 & $54,5 \%$ & 9 & $81,8 \%$ & $27,3 \%$ \\
\hline 39 & R39 & 8 & $72,7 \%$ & 11 & $100 \%$ & $27,3 \%$ \\
\hline 40 & $\mathrm{R} 40$ & 7 & $63,6 \%$ & 11 & $100 \%$ & $36,4 \%$ \\
\hline 41 & R41 & 8 & $72,7 \%$ & 11 & $100 \%$ & $27,3 \%$ \\
\hline 42 & R42 & 5 & $45,4 \%$ & 10 & $90,9 \%$ & $45,4 \%$ \\
\hline 43 & R43 & 4 & $36,4 \%$ & 10 & $90,9 \%$ & $54,5 \%$ \\
\hline 44 & R44 & 7 & $63,6 \%$ & 11 & $100 \%$ & $36,4 \%$ \\
\hline 45 & R45 & 7 & $63,6 \%$ & 10 & $90,9 \%$ & $27,3 \%$ \\
\hline \multicolumn{3}{|c|}{ Total } & $64,41 \%$ & & $93,53 \%$ & $29,12 \%$ \\
\hline
\end{tabular}

\section{Pembahasan}

Hasil dari pengabdian masyarakat yang dilakukan dalam sosialisasi metode pemeriksaan IVA pada wanita usia subur mengalami peningkatan. Walaupun nyatanya peningkatan ini tidak mengakibatkan seluruh WUS akhirnya ingin melakukan pemeriksaan
IVA. Tetapi setidaknya minat melakukan pemeriksaan IVA meningkat setelah diberikan sosialisasi /penyuluhan tentang pentingnya pemeriksaan IVA. Pemeriksaan IVA sebagai salah satu pencegahan dini kanker serviks. IVA tampak efektif untuk membantu penapisan dalam proses pencegahan kanker serviks. 
payudara dan kanker leher rahim.

Notoatmodjo, S. (2014). Metodelogi Penelitian Kesehatan.

Riskesdas. (2018). Badan Penelitian dan Pengembangan Kesehatan 2018.

Setyani, R. A. (2018). Penerapan program deteksi dini kanker serviks. 3(2), 12-16.

Sholihah, A. N., \& Sulistyorini, E. (2015). Hubungan Antara Sikap Pencegahan Kanker Serviks Dengan Minat Deteksi Dini Menggunakan Inspeksi Visual Asam Asetat Pada Wanita Usia Subur Di RW IV Desa Cangkol Mojolaban Sukoharjo. 102-116.

Sugiyanto, \& Febriana, T. N. (2016). Pengaruh pendidikan kesehatan tentang kanker serviks terhadap minat pemeriksaan iva pada kelompok ibu pengajian. 12(2), 158-162.

WHO. (2016). Cervical Cancer. 